\title{
Physical-chemical and microbiological quality of water used for public supply in the municipality of Alvorada D'Oeste, Rondônia, Brazil
}

\author{
Qualidade físico-química e microbiológica da água de abastecimento público do município de
} Alvorada D'Oeste, Rondônia, Brasil

Calidad físico-química y microbiológica del agua utilizada para el suministro público en el municipio de Alvorada D'Oeste, Rondônia, Brasil

Received: 08/12/2021 | Reviewed: 08/22/2021 | Accept: 08/26/2021 | Published: 08/29/2021

\author{
Thander Jacson Nunes Calente \\ ORCID: https://orcid.org/0000-0003-0162-589X \\ Universidade Federal de Santa Catarina, Brazil \\ E-mail: thandercalente.tj@gmail.com \\ Grazieli Nunes Calente Santos \\ ORCID: https://orcid.org/0000-0001-6751-6712 \\ Serviço Autônomo de Água e Esgoto, Brazil \\ E-mail: grazicalente@gmail.com \\ Wesclen Vilar Nogueira \\ ORCID: https://orcid.org/0000-0002-9353-847X \\ Universidade Federal do Rio Grande, Brazil \\ E-mail: wesclenvilar@gmail.com
}

\begin{abstract}
The study analyzed the physical-chemical and microbiological parameters carried out by the Autonomous Water and Sewage Service (AWSS) of the Municipality of Alvorada D'Oeste, Rondônia, Brazil. The parameters analyzed were: $\mathrm{pH}$, turbidity, free residual chlorine, total coliforms (TC), thermotolerant coliforms (TTC) and heterotrophic bacteria. The values of hydrogen potential $(\mathrm{pH})$ were obtained with a digital $\mathrm{pH}$ meter. The analyzes were carried out the 2013 to 2019. The turbidity and free residual chlorine values were obtained according to the method of the Practical Manual of Water Analysis of the National Health Foundation (FUNASA). To determine the microbiological parameters, Petrifilm ${ }^{\mathrm{TM}}$ plates $\left(3 \mathrm{M}^{\mathrm{TM}}\right.$ do Brasil Ltda) were used, following the manufacturer's guidelines. The analyzed values were compared with reference values described in Consolidation Ordinance $n^{\circ}$. 5, of September 28, 2017, of the Ministry of Health (MS) which sets the standards for potability of water intended for human consumption. The results varied for all parameters evaluated: $\mathrm{pH}$ (3.11 to 8.24), turbidez (0.02 to 3,01), TC (0 to $100 \%)$, TTC (0 to $100 \%)$ and heterotrophic bacteria ( 85 to $100 \%$ ). The values obtained for free residual chlorine were the only parameter to follow the reference values. The highest contamination for TC and heterotrophic bacteria were reported in 2019, higher the limits established in Brazilian legislation. Thus, the water was characterized as unfit for consumption and requires severe control for TC and heterotrophic bacteria.
\end{abstract}

Keywords: Chlorine; Coliforms; Turbidity; Water treatment.

\section{Resumo}

$\mathrm{O}$ estudo analisou os parâmetros físico-químicas e microbiológicas realizadas pelo Serviço Autônomo de Água e Esgoto (SAAE) do município de Alvorada D'Oeste, Rondônia, Brasil. Os parâmetros analisados foram: pH, turbidez, cloro residual livre, coliformes totais (CT), coliformes termotolerantes (CTT) e bactérias heterotróficas. Os valores do potencial de hidrogênio $(\mathrm{pH})$ foram obtidos com um medidor de $\mathrm{pH}$ digital. As análises foram realizadas no período de 2013 a 2019. Os valores de turbidez e cloro residual livre foram obtidos conforme método do Manual Prático de Análise de Água da Fundação Nacional de Saúde (FUNASA). Para determinação dos parâmetros microbiológicos, foram utilizadas placas Petrifilm ${ }^{\mathrm{TM}}\left(3 \mathrm{M}^{\mathrm{TM}}\right.$ do Brasil Ltda), seguindo as orientações do fabricante. Os valores analisados foram comparados com os valores de referência descritos na Portaria de Consolidação n⿳. 5 , de 28 de setembro de 2017 do Ministério da Saúde (MS) que estabelece os padrões de potabilidade da água destinada para consumo humano. Os resultados variaram para todos os parâmetros avaliados: pH (3,11 a 8,24), turbidez (0,02 a 3,01), CT (0 a 100\%), CTT (0 a 100\%) e bactérias heterotróficas (85 a 100\%). Os valores obtidos para cloro residual livre foram os únicos a seguir os valores de referência. As maiores contaminações por CT e bactérias heterotróficas foram relatadas em 2019, superiores aos limites estabelecidos na legislação brasileira. Assim, a água foi caracterizada como imprópria para consumo e requer controle severo para CT e bactérias heterotróficas.

Palavras-chave: Cloro; Coliformes; Turbidez; Tratamento de água. 


\section{Resumen}

El estudio analizó los parámetros físicoquímicos y microbiológicos realizados por el Servicio Autónomo de Agua y Alcantarillado (SAAA) del Municipio de Alvorada D'Oeste, Rondônia, Brasil. Los parámetros analizados fueron: pH, turbidez, cloro libre de residuos, coliformes totales (CT), coliformes termotolerantes (CTT) y bacterias heterótrofas. Los valores de potencial de hidrógeno $(\mathrm{pH})$ se obtuvieron con un medidor de $\mathrm{pH}$ digital. Los análisis se realizaron desde el año 2013 hasta el 2019. Los valores de turbidez y cloro residual libre se obtuvieron según el método del Manual Práctico de Análisis de Aguas de la Fundação Nacional de Saúde (FUNASA). Para la determinación de los parámetros microbiológicos se utilizaron placas Petrifilm ${ }^{\mathrm{TM}}\left(3 \mathrm{M}^{\mathrm{TM}}\right.$ do Brasil Ltda), siguiendo las instrucciones del fabricante. Los valores analizados se compararon con los valores de referencia descritos en la Ordenanza de Consolidación n. 5, del 28 de septiembre de 2017, del Ministerio de Salud (MS) que establece los estándares de potabilidad del agua destinada al consumo humano. Los resultados variaron para todos los parámetros evaluados: $\mathrm{pH}$ $(3,11$ a 8,24), turbidez $(0,02$ a 3,01), CT (0 a 100\%), CTT (0 a 100\%) y bacterias heterótrofas (85 a $100 \%)$. Los valores obtenidos para el cloro residual libre fueron los únicos que siguieron los valores de referencia. Las mayores contaminaciones por CT y bacterias heterótrofas se reportaron para el año 2019, superiores a las determinadas en la Ordenanza de Consolidación no. 5. Por lo tanto, el agua se caracteriza como no apta para el consumo y requiere un control severo de CT y bacterias heterótrofas.

Palabras clave: Cloro; Coliformes; Turbiedad; Tratamiento de aguas.

\section{Introduction}

Water is a fundamental and indispensable component of human survival (Wolkmer, 2012). In Brazil, according to Law $n^{\circ}$. 9,433 of 8 January 1997, it is right to have access to drinking water without any risk to consumers' health (Brasil, 1997). Consolidation Ordinance $n^{\circ} .5$ of September 28, 2017, also reports that water destined for human consumption by a water supply system must meet the potability standards following physical and biological prerequisites (Brasil, 2017). Thus, the water must be free of contaminants, colorless and odorless (Abbasnia et al., 2018; Silva, 2020).

The biological prerequisites can suffer interference by the process of occupation of hydrographic basins (Duarte et al., 2020), mainly those related to the urbanization process (domestic sewage, pits), agricultural management (pesticides), and livestock (animal feces) developed in a disorderly and irregular manner (Santos et al., 2018). The percolation of rainwater and runoff can alter the quality of surface and underground water by the procedure of leaching of microorganisms from the process of disordered occupation of hydrographic basins (Moura et al., 2010). Although water does not provide the necessary conditions for the multiplication of microorganisms, they can remain in the fluid long enough to guarantee their transmission (Reis et al., 2020). In addition, in water treatment plants (WTPs), microorganisms can become resistant to disinfectant actions when present for long periods (Tenório, 2016; Silva et al., 2019).

Coliforms is a group of microorganisms widely distributed in nature, including in water (Yousefi, et al. 2018; Rodrigues, et al. 2020). This group includes thermotolerant coliforms (TTC), microorganisms used as a standard to measure the quality of surface water intended for supply, recreation and agricultural activities (irrigation and fish farming) (Peres, 2011; Ceballos \& Diniz, 2017). Escherichia coli is a TTC found naturally in the gut of homeotherms with particular importance. Thus, the presence of TTC or Escherichia coli in the water indicates fecal contamination and can be used as an indicator of hygienic-sanitary quality (Braga, 2014). When ingested in large quantities, it can cause intestinal and urinary tract infections (Buzanello \& Martinhago, 2008; Lacerda et al., 2019).

The present study aimed to evaluate the results of the physical-chemical and microbiological analyzes carried out by the water treatment plant (WTP) in the municipality of Alvorada D'Oeste, Rondônia, Brazil, between the years 2013 to 2019 , comparing with the reference values described in Consolidation Ordinance $\mathrm{n}^{\circ}$. 5, of September 28, 2017, of the Ministry of Health (MS) which sets the standards for potability of water intended for human consumption. 


\section{Methodology}

The data presented in this study were obtained from Autonomous Water and Sewage Service (AWSS) of the Municipality of Alvorada D’Oeste, Rondônia, Brazil. The information comprises the monitoring period between the years 2013 to 2019 . AWSS conducts monthly analyzes at 7 sample points located in the urban area of the municipality (Table 1 ).

Table 1. Coordinates of sample points.

\begin{tabular}{ccc}
\hline Points & Coordinates \\
\hline 1 & $11^{\circ} 20^{\prime} 24.59 " \mathrm{~S}$ & $62^{\circ} 18^{\prime} 5.61^{\prime \prime} \mathrm{W}$ \\
2 & $11^{\circ} 20^{\prime} 22.65^{\prime \prime S}$ & $62^{\circ} 17^{\prime} 59.17^{\prime \prime} \mathrm{W}$ \\
3 & $11^{\circ} 20^{\prime} 1.24 " \mathrm{~S}$ & $62^{\circ} 16^{\prime} 34.72^{\prime \prime} \mathrm{W}$ \\
4 & $11^{\circ} 21^{\prime} 16.88^{\prime \prime S}$ & $62^{\circ} 17^{\prime} 3.33^{\prime \prime} \mathrm{W}$ \\
5 & $11^{\circ} 21^{\prime} 0.97 " \mathrm{~S}$ & $62^{\circ} 17^{\prime} 47.23^{\prime \prime} \mathrm{W}$ \\
6 & $11^{\circ} 20^{\prime} 43.45^{\prime \prime S}$ & $62^{\circ} 17^{\prime} 4.24^{\prime \prime} \mathrm{W}$ \\
7 & $11^{\circ} 20^{\prime} 58.12^{\prime \prime S}$ & $62^{\circ} 17^{\prime} 17.44^{\prime \prime} \mathrm{W}$ \\
\hline
\end{tabular}

Source: Authors.

Through the public supply of drinking water, AWSS serves $95 \%$ of the municipal population. The water is taken from the Ribeirão do Cacau River and pumped to the water treatment plant (WTP) where it is treated and distributed. The region presents tropical climatic conditions, it is characterized by a dry and a rainy season (Cavalcanti, et al. 2016; Nogueira, et al. 2020), with temperatures ranging between $19-33^{\circ} \mathrm{C}$ and annual precipitation around $2500 \mathrm{~mm}$ (Krusche et al., 2005). The rainy period occurs from October to April, and the period from June to August corresponds to the drought period, May and September are considered transition months (Krusche et al., 2005).

The analyzes performed by AWSS comprise the physical-chemical parameters, which are $\mathrm{pH}$, turbidity, and free residual chlorine, and the microbiological parameters, comprising total coliforms (TC), thermotolerant coliforms (TTC), and heterotrophic bacteria. The values of hydrogen potential $(\mathrm{pH})$ were obtained with a digital $\mathrm{pH}$ meter (ST 2100-F, Ohaus, Brazil). To obtain the values of turbidity and free residual chlorine, the method established in the Practical Water Analysis Manual of the National Health Foundation (FUNASA) was used, being the nephelometric and determination method, respectively (Brasil, 2006). To determine the microbiological parameters, Petrifilm ${ }^{\mathrm{TM}}$ plates $\left(3 \mathrm{M}^{\mathrm{TM}}\right.$ do Brasil Ltda) were used, following the manufacturer's guidelines.

For physical-chemical analyzes, the results are presented as the average of the duplicate analyzes and for microbiological analysis, the data are presented in percentage of contamination. Physical-chemical and microbiological analyzes were carried out at all points analyzed.

\section{Results and Discussion}

For the physical-chemical parameters analyzed by AWSS, only residual free chlorine (1.99 mg/L to $1.33 \mathrm{mg} / \mathrm{L}) \mathrm{was}$ in accordance with the values described in Consolidation Ordinance no. 5, of September 28, 2017 (0.20 to $2.00 \mathrm{mg} / \mathrm{L})$ for the evaluated period. The values for turbidity did not change above that established by the ordinance (<1.0 NTU) in 2014 , but for the remaining years, at least one month showed values above the established. For $\mathrm{pH}$, in all years evaluated at least in one month, the values were not in accordance with those established in legislation (Table 2). 
Table 2. Physical-chemical analyzes of water from the municipality of Alvorada D'Oeste, between the years 2013 to 2019.

\begin{tabular}{|c|c|c|c|c|c|c|c|c|c|c|c|c|c|}
\hline \multirow{2}{*}{ Period } & \multirow{2}{*}{ Parameters } & \multicolumn{12}{|c|}{ Months } \\
\hline & & 01 & 02 & 03 & 04 & 05 & 06 & 07 & 08 & 09 & 10 & 11 & 12 \\
\hline \multirow[t]{3}{*}{2013} & $\mathrm{pH}$ & $5.07 *$ & $4.93 *$ & $5.5^{*}$ & $5.93 *$ & 6.4 & 6.4 & 6.7 & 6.81 & 6.63 & $5.88 *$ & $5.8^{*}$ & $5.7 *$ \\
\hline & Turbidity (NTU) & $3.01 *$ & $1.18^{*}$ & 0.97 & 0.62 & 0.30 & 0.20 & 0.10 & 0.07 & 0.23 & 0.60 & 0.90 & 0.96 \\
\hline & Residual free chlorine (mg/L) & 1.98 & 1.99 & 1.99 & 1.93 & 1.6 & 1.5 & 1.49 & 1.45 & 1.47 & 1.5 & 1.9 & 1.76 \\
\hline \multirow[t]{3}{*}{2014} & $\mathrm{pH}$ & $5.68 *$ & $5.74 *$ & 6.04 & 6.37 & 6.3 & 6.4 & 6.03 & 6.03 & 6.31 & $5.76^{*}$ & $5.8^{*}$ & $4.99 *$ \\
\hline & Turbidity NTU) & 0.19 & 0.22 & 0.06 & 0.06 & 0.10 & 0.30 & 0.03 & 0.03 & 0.27 & 0.40 & 0.90 & 0.19 \\
\hline & Residual free chlorine (mg/L) & 1.52 & 1.5 & 1.49 & 1.49 & 1.5 & 1.5 & 1.33 & 1.33 & 1.5 & 1.5 & 1.5 & 1.5 \\
\hline \multirow[t]{3}{*}{2015} & $\mathrm{pH}$ & $5.47 *$ & $5.37 *$ & $4.75^{*}$ & $5.5^{*}$ & $5.85^{*}$ & 6.4 & 6.97 & 6.79 & 6.72 & 6.2 & $5.84 *$ & $5.4^{*}$ \\
\hline & Turbidity (NTU) & 0.07 & 0.04 & 0.16 & 0.07 & 0.10 & 0.20 & 0.23 & 0.10 & 0.17 & 0.20 & 1.00 & $1.45^{*}$ \\
\hline & Residual free chlorine (mg/L) & 1.5 & 1.54 & 1.44 & 1.48 & 1.5 & 1.5 & 1.5 & 1.5 & 1.49 & 1.5 & 1.4 & 1.5 \\
\hline \multirow[t]{3}{*}{2016} & $\mathrm{pH}$ & $5.91 *$ & $5.37^{*}$ & $4.63 *$ & $4.89 *$ & $5.89 *$ & $5.76 *$ & 6.5 & 6.64 & 6.11 & 6.2 & 6.1 & $5.58 *$ \\
\hline & Turbidity (NTU) & 0.98 & $1.48^{*}$ & 0.58 & 0.30 & 0.30 & 0.20 & 0.16 & 0.39 & 0.37 & 0.70 & $2.08 *$ & 0.45 \\
\hline & Residual free chlorine (mg/L) & 1.5 & 1.56 & 1.50 & 1.50 & 1.50 & 1.50 & 1.49 & 1.49 & 1.45 & 1.50 & 1.80 & 1.53 \\
\hline \multirow[t]{3}{*}{2017} & $\mathrm{pH}$ & $5.52 *$ & $5.8^{*}$ & 6.0 & 6.2 & 6.1 & 6.2 & 6.15 & $5.96 *$ & $5.25 *$ & $5.77 *$ & $3.11 *$ & $3.28 *$ \\
\hline & Turbidity (NTU) & 0.86 & 0.82 & 0.67 & 0.51 & 0.30 & 0.50 & 0.09 & 0.26 & 0.99 & 0.40 & $1.07 *$ & $1.05^{*}$ \\
\hline & Residual free chlorine $(\mathrm{mg} / \mathrm{L})$ & 1.69 & 1.5 & 1.48 & 1.53 & 1.4 & 1.4 & 1.45 & 1.48 & 1.57 & 1.6 & 1.8 & 1.75 \\
\hline \multirow[t]{3}{*}{2018} & $\mathrm{pH}$ & $4.02 *$ & $5.91 *$ & - & - & - & - & - & - & - & $5.67 *$ & $5.67 *$ & 5.32 \\
\hline & Turbidity (NTU) & 0.45 & 0.02 & 0.02 & 0.17 & 0.20 & 0.20 & 0.05 & 0.03 & 0.11 & 0.50 & 0.50 & $1.66^{*}$ \\
\hline & Residual free chlorine $(\mathrm{mg} / \mathrm{L})$ & 1.5 & 1.5 & 1.5 & 1.5 & 1.5 & 1.5 & 1.5 & 1.5 & 1.47 & 1.5 & 1.5 & 1.49 \\
\hline \multirow[t]{3}{*}{2019} & $\mathrm{pH}$ & $5.38^{*}$ & $5.59 *$ & 6.19 & 8.24 & 6.6 & 7.5 & 7.3 & 7.56 & 7.01 & 6.6 & $5.48 *$ & $3.47 *$ \\
\hline & Turbidity (NTU) & 0.40 & 0.25 & 0.30 & 0.64 & 0.50 & 0.10 & 0.40 & 0.40 & $1.57 *$ & $2.20 *$ & $4.82 *$ & 0.94 \\
\hline & Residual free chlorine (mg/L) & 1.5 & 1.5 & 1.44 & 1.49 & 1.5 & 1.5 & 1.44 & 1.49 & 1.65 & 1.8 & 2.00 & 1.27 \\
\hline
\end{tabular}

Reference values described in Consolidation Ordinance $\mathrm{n}^{\circ} .5: \mathrm{pH}=6.0$ to 9.0, Turbidity $=<1.0 \mathrm{NTU}$, Residual free chlorine $=0.20$ to $2.0 \mathrm{mg}$ $/ \mathrm{L}, *$ altered values, - = analysis not performed. Source: Authors.

For microbiological analyzes, in 2013, in the months of January and November, 5 and $2 \%$ of the samples were positive for TC and TTC, respectively. For the year 2014, the month of January, 21 and $3 \%$ of the samples were positive for TC and TTC, respectively. In the same year, in the month of May, 14\% of the samples were positive for heterotrophic bacteria. In 2018, no analyzes were performed in January, in December 1\% of the analyzed samples were positive for TC. In 2019, bacteriological analyzes were high when compared to previous years. For the months of April, June and August, $14.2 \%$ of the samples were positive for TC, in March 15\% of the samples were positive for TC. In March, April, June, August, November and December, all samples analyzed were positive for heterotrophic bacteria, in July, 55.5\% (Table 3). 
Table 3. Bacteriological analysis of water from the municipality of Alvorada D'Oeste between the years 2013 to 2019.

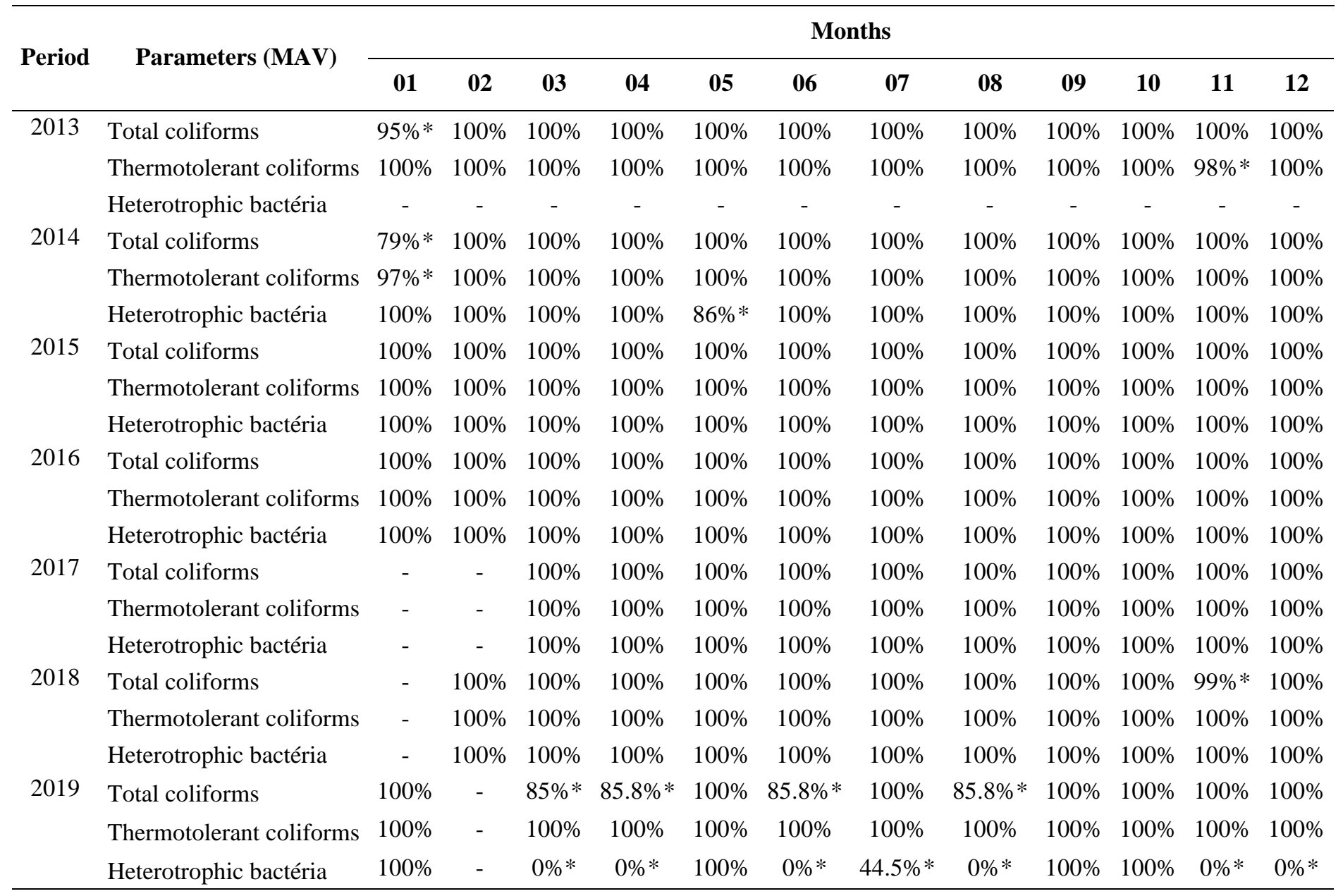

Reference values described in Consolidation Ordinance $\mathrm{n}^{\circ} .5$ : microbial growth must $100 \%$ absent. MAV $=$ maximum allowed value, $*=$ changed values, - = analysis not performed. Source: Authors.

According to the results, an increase in turbidity and a decrease in $\mathrm{pH}$ during the rainy season were observed. This process may be associated with the influence of rain that facilitates the entrance of alien material (solid materials, foliage, algae, debris, and organic sediments) into the WTP, making it difficult to control turbidity (Almeida et al., 2017; Buzelli et al., 2013). Due to the amount of particulate material, the filtration and coagulation process employed by WTP may not be effective and may be impaired (Mendes \& Ferreira, 2014).

Changes in $\mathrm{pH}$ can also be associated with the addition of a coagulant agent, ferrous aluminum sulfate, a chemical applied to reduce water turbidity (Lemos et al., 2020). However, the use of alkalinized products reduces the $\mathrm{pH}$ of the water, resulting in incrustations in the pipes (Asghari et al., 2018), corrosion in the drains and algae growth in the water distribution systems, allowing the growth of microorganisms (total coliforms, heterotrophic bacteria, mesophiles) (Silva et al., 2016). Carvalho et al. (2020) relates the presence of heterotrophic bacteria and acidic $\mathrm{pH}$ with the increase of nitrite in the water in the rainy season. Mata and Campos (2020) associate the growth of TC and heterotrophic bacteria with the lack of maintenance in outdated reservoirs, old pipes or infiltrations in the distribution systems. Oliveira et al. (2018), attributes the growth of TC and heterotrophic bacteria to poor pipe conservation.

According to Freire and Lima (2012) the growth of bacteria occurs under conditions of deterioration of free residual chlorine in the water distribution networks. This degradation process may explain the high bacteriological incidence. Another fact that can influence this result is the natural evaporation process, which can interfere with biological, physical and chemical 
characteristics, increasing the concentration of nutrients, salinity, and conductivity, contributing to the high turbidity values in the period with the lowest rainfall (Nagata et al., 2015; Shuangchen et al., 2016; Diniz, 2017). According to Mendonça et al. (2017), the temperature influences the residual loss and evaporation of free residual chlorine in the water present during the distribution process, increasing bacterial growth in WTPs. This increase also contributes to the formation of biofilms in plumbing.

The correlation between the parameters evaluated where it was evidenced a decrease in $\mathrm{pH}$, an increase in turbidity and bacterial growth can be related to several factors. Especially those associated with the integrity of the filters used by AWSS, as well as the maintenance of the distribution systems, which may have contributed to the physical-chemical and microbiological deviations. In this way, it is demonstrated the need for reforms and maintenance (maintenance and replacement of sand, fine and medium gravel, medium and coarse gravel) of the AWSS system during the periods from January 2012 to November 2019. The lack of maintenance decreases performance and affects the integrity of the WTP, changing the quality of the water distributed in distribution networks (Hachem et al., 2020).

\section{Conclusion}

The only physical-chemical parameter following the values described in Consolidation Ordinance $\mathrm{n}^{\circ}$. 5, of September 28, 2017 of the water distributed by the WTP in the municipality of Alvorada D'Oeste was the residual free chlorine. The bacteriological analyzes carried out in 2015, 2016, 2017 and 2018 were within the parameters described in Consolidation Ordinance $n^{\circ} .5$, of September 28, 2017. In 2019, 100\% of the samples showed contamination by heterotrophic bacteria and total coliforms, thus, water was characterized as unfit for consumption.

\section{References}

Abbas, A., Nader, Y., Amir, H. M., Ramin, N., Majid, R., Mahmood Y., \& Mahmood, A. (2018). Evaluation of groundwater quality using water quality index and its suitability for assessing water for drinking and irrigation purposes: Case study of Sistan and Baluchistan province (Iran). Human and Ecological Risk Assessment, 1 (1), 988-1005. https://doi.org/10.1080/10807039.2018.1458596

Almeida, M. C., MM Silva, M. M., \& Paula, M. (2017). Performance evaluation of water treatment plant in relation to water turbidity, color and pH. Environmental management and Technologies, 5 (1), 25-40. http://dx.doi.org/10.9771/gesta.v5i1.17396

Asghari, F. B., Jaafari, J., Yousefi, M., Mohammadi, A. A., \& Dehghanzade, R. (2018). Evaluation of water corrosion, scaling extent and heterotrophic plate count bacteria in asbestos and polyethylene pipes in drinking water distribution system. Human and Ecological Risk Assessment, 24 (1), 1138-1149. https://doi.org/10.1080/10807039.2017.1407632

Braga, F. P. (2014). Performance evaluation of a water treatment plant in the city of Juiz de Fora - MG. MSc diss., Universidade Federal Juiz de Fora.

Brasil. Lei no 9.433, de 8 de janeiro de 1997. Diário Oficial da União, Brasília, DF, 1997.

Brasil. 2006. Manual prático de análise de água. (2rd ed.), Fundação Nacional de Saúde.

Brasil. 2017. Portaria de Consolidação nº 5, de 28 de setembro de 2017. Diário Oficial da União, Ministério da Saúde.

Buzanello, E. B., \& Martinhago, M. W. (2008). Determination of total and thermotolerant coliforms in the water of lake the municipal of Cascavel, Paraná. Revista Brasileira de Biociências, 6 (1), 59-60.

Buzelli, G. M., \& Cunha-Santino, M. B. (2013). Diagnosis and analysis of water quality and trophic state of Barra Bonita reservoir, SP. Environment \& Water, 8, (1), 186-205. http://dx.doi.org/10.4136/ambi-agua.930

Cavalcanti, I. F. A., Ferreira, N. J., Silva, M. G. A. J., \& Dias, M. A. F. S. (2016). Weather and climate in BrazilOficina de Textos.

Carvalho, D. A. F., \& Monteiro, C. A. B. (2020). Avaliação da qualidade da água para consumo humano na zona urbana de Campo Maior - PI. Revista Brasileira de Gestão Ambiental, 14 (1), 69-75.

Ceballos, B. S. O., \& Diniz, C. R. (2017). Técnicas de microbiologia sanitária e ambiental. (21st ed.), Editora Universidade Estadual da Paraíba.

Diniz, I. S. M. (2017). The quality of water availability of the Cruzeta reservoir in the tropical semi-arid region in an event of prolonged drought. MSc diss., Universidade Federal do Rio Grande do Norte. 
Duarte, M. L. Filho, L. P. S., Brito, W. B. M., \& Siva, T. A. (2020). Determination of soil erodibility by means of two indirect methods in a watershed in the southern region of the state of Amazonas, Brazil. Brazilian Journal of Geomorphology, 21 (2), 329-341. http://dx.doi.org/10.20502/www.ugb.org.br rbg.v21i2.1533

Freire, R. C., \& Lima, R. D. A. (2012). Heterotrophic bacteria in the distribution system of drinking water in the city of Olinda-PE and its importance to the public health. J Manag Prim Health Care, 3 (2), 91- 95. https://doi.org/10.14295/jmphc.v3i2.144

Hachem, B. P., Tavares, A. N., Noronha, A. M., Cardoso, A. R. B., Andrade, M. A., \& Lucena, W. M. (2020). Analysis of the causes of occurrences in the SAA of the Pará sanitation company in Belém Do Pará. Brazilian Journal. of Development, 6, 17013-17021. https://doi.org/10.34117/bjdv6n4-027

Krusche, A. V., Ballester, M. V. R., Victoria, R. L., Bernardes, M. C., Leite, N. K., \& Hanada, L. (2005). Effects of land use changes in the biogeochemistry of fluvial systems of the Ji-Paraná River basin, Rondônia. Acta. Amazônica, 35 (1), 197-205. https://doi.org/10.1590/S0044-59672005000200009

Lacerda, A. B., Räder, A. S., \& Lopes, E. S. (2019). The efficiency of coliform removal in a conventional water treatment plant. Brazilian Journal of Development, 5 (1), 7523-7539. https://doi.org/10.34117/bjdv5n6-225

Lemos, K.S., Filho, S. Q. A., \& Cavallini, G. S. (2020). Comparative evaluation between ferrous aluminum sulfate and aluminum polychloride coagulants for water treatment: economic feasibility study. Challenges Magazine, 7, 109-119. http://dx.doi.org/10.20873/uftv7-7824

Mata, T. V. E., \& Campos, L. L. (2020). Análise da qualidade microbiológica da água e da superfície dos bebedouros de um hospital regional do Distrito Federal-DF. Revista de saúde, 7, 21-29.

Mendes, L. S., \& Ferreira I. M. (2014). Influence of seasonality on the quality of raw water in the Municipality of Ituiutaba-MG. Revista Brasileira de Geografia Médica e da Saúde, 10, 97-105.

Mendonça, M. H. M., Roseno, S. A. M., Cachoeira, T. R. L. C., Silva, T. R. L. C., Jácome, A. F.S., \& Júnior, A. T. J. (2017). Bacteriological analysis of drinking water sold by water tank trucks. Revista Ambiente e Água, 12, 268-475. https://doi.org/10.4136/ambi-agua.1934

Moura, L. H. A., Boaventura, G. R., \& Penelli, M. P. (2010). The water quality as an indicator of land use and occupation: Gama Basin-DF. New Chemistry, 33, 97-103. http://dx.doi.org/10.1590/S0100-40422010000100018

Nagata, Y., Usui, K., \& Bonn, M. (2015). Molecular Mechanism of Water Evaporation. Physical Review Letters, 115, 236-102. https://doi.org/10.1103/PhysRevLett.115.236102

Nogueira, W. V., Oliveira, F. K., Marimón-Sibaja, K. V., Garcia, S. O., Kupski, L., Souza, M. M., Tesser, M. B., \& Garda-Buffon, J. (2020). Occurrence and bioacessibility of mycotoxins in fish feed. Food Additives \& Contaminants, 1: 1-8. https://doi.org/10.1080/19393210.2020.1766577

Oliveira, L. F., Oliveira, B. O. S, \& Lima, L. B. (2018). Evaluation of the water quality of three streams in the area urban of Humaitá-AM. Journal of Environmental Sciences, 12, 25-33. http://dx.doi.org/10.18316/rca.v12i3.3606

Peres, B. M. (2011). Pathogenic and indicator bacteria in drinking water treatment plants, in sewage treatment plants and in a creek contaminated with raw sewage. MSc diss., Universidade de São Paulo.

Reis, D. A., Nascimento, L. P., Marques, L. S., Oliveira, E. G., Ferreira. C. S., Chagas, I. A. S., Roeser, H. M. P., \& Santiago, A. F. (2020). Restrição do uso das águas da bacia hidrográfica do rio Matipó devido à contaminação microbiológica. Revista Mineira de Recursos Hídricos, 1 (1): 1-14.

Rodrigues, M. V., Magalhães-Lopes, V., Nogueira W. V., \& Bianchini-Pontuschka, R. (2020). Evaluación microbiológica de una estación de piscicultura en el Territorio Central del Estado de Rondônia, Brasil. Revista Colombiana de Ciência Animal, 12, 743-743. https://doi.org/10.24188/recia.v12.n1.2020.743

Santos, R. C. L., Lima, A.S., Cavalcanti, E. B., Melo, C. M., \& Marques, M. N. (2018). Application of indexes to assess the water quality of coastal basin of the Sapucaia in Sergipe. Sanitary and Environmental Engineering, 23, 33-46. http://dx.doi.org/10.1590/s1413-41522017159832

Shuangchen, M., Chai Jin, C. G., \& Yu Weijing, Z. S. (2016). Research on desulfurization wastewater evaporation: present and future perspectives. Renewable and Sustainable Energy Reviews, 58, 1143-1151. http://dx.doi.org/10.1016/j.rser.2015.12.252

Silva, A. B., Silva, J. C., Melo, B. F., Nascimento, R. F., Duarte, J. S., \& Filho, E. D. D. S. (2019). Microbiological analysis of drinking water in public schools in the city of Esperança/PB. SAJEBTT, 6, 15-26.

Silva, A. J. J. (2020). Aspects about of the water treatment for human consumption in an ETA of the water and sewer municipal service of the city of Ouro Preto/MG. Revista de Engenharia e Tecnologia, 12, 285-300.

Silva, L. J., Lopes, L. G., \& Amaral. L. A. (2016). Quality of public-supply water in Jaboticabal city, Brazil. Sanitary and Environmental Engineering, 21, 615-622. https://doi.org/10.1590/S1413-41522016121151

Tenório, M. A. (2016). Análise dos padrões de potabilidade da água para o consumo humano - Porto Velho - RO, Brasil. MBA diss., Centro Universitário São Lucas.

Wolkmer. A. C., Augustin, S., \& Wolkmer, M. F. (2012). The "new" right to water in the Latin-American constitutionalism. Inter Interdisc INTERthesis, 9, 51-69. https://doi.org/10.1080/08263663.2018.1456141

Yousefi, M., Saleh, H. N., Yaseri, M., Mahvi, A. H., Soleimani, H., Saeedi, Z., Zohdi, S., \& Mohammadi, A. A. (2018). Data on microbiological quality assessment of rural drinking water supplies in Poldasht county. Data in Brief, 17, 763-769. https://doi.org/10.1016/j.dib.2018.02.003 